\title{
Kajian Awal Pemanenan Siput Laut (Gastropoda) di Pantai Krakal, Yogyakarta III: Aktivitas Wisatawan
}

\section{A Preliminary Study on Marine Snails Harvest (Gastropods) in Krakal Beach, Yogyakarta III: Tourist Activities}

\author{
Santi Ari Andi ${ }^{1}$, Felicia Zahida ${ }^{*}$, dan B. Boy Rahardjo Sidharta1 \\ Fakultas Biologi, Universitas Atma Jaya Yogyakarta, Jl. Babarsari 44, Yogyakarta \\ E-mail: feliciazda@mail.uajy.ac.id *Penulis korespondensi
}

\begin{abstract}
This study wanted to elucidate the role of tourists activities to the beach such as Krakal Beach, Yogyakarta. The method used in this research was direct interview to the visitors using accidental sampling with the help of prepared questionnaire. This study showed that $86 \%$ visitors were in their school age. Person in this age like such a challenge like what they met during beach visit. Those make the visitation frequency quite high by repeating their visit $(\mathbf{5 3 , 5 \% )}$. Shells and shells handicrafts has been proven to be the reason why visitors come back to visit the beach $(79 \%)$. Apparently, visitors agree that the snails' forms and colors are attactive (70,9\%), beautiful and unique $(\mathbf{7 5 , 6 \%})$, but only $14 \%$ said that it shouldn't be disturb by human activities. Their attractiveness to the snails did not make them to collect intentionally, enough for them to see and let them go $(66,2 \%)$. They did not agree that visitors collected them $(51,2 \%)$, but they agree harvesters make a souvenirs and get an income from this activity $(67,4 \%)$. In short, they were much environment friendly $(57 \%)$ rather than economic friendly $(43 \%)$.
\end{abstract}

Key words: shells, souvenirs, and tourist activities

Diterima: 30 Oktober 2004, disetujui: 31 Desember 2005

\section{Pendahuluan}

Pantai Krakal telah dikembangkan menjadi daerah wisata pantai yang cukup dikenal masyarakat Yogyakarta. Wisatawan dalam negeri terutama dari pulau Jawa, bila berkunjung ke Yogyakarta seringkali menyempatkan diri ke pantai-pantai selatan Yogyakarta termasuk pantai Krakal. Dari tahun ke tahun kunjungan wisatawan makin meningkat, seiring dengan diperbaikinya jalanjalan menuju ke lokasi tersebut. Data Dinas Pariwisata dan Kebudayaan menunjukkan kenaikan jumlah wisatawan Pantai Selatan Gunung Kidul, yaitu dari tahun 2000 sejumlah 279.322, tahun 2001 sejumlah 343.143, tahun 2002 sejumlah 333.183, tahun 2003 sejumlah
349.419 dan tahun 2004 sejumlah 370.022 (Cahyaningrum, 2005).

Peningkatan kunjungan wisatawan diperkirakan akan memberi tekanan pada daerah wisata Pantai Krakal ini. Namun demikian belum diketahui, apakah penyebab penurunan populasi Gastropoda adalah wisatawan atau penduduk pemanen cangkang setempat. Aktivitas pemanen/penduduk setempat sendiri telah diketahui (Zahida et al. 2005), dan dalam penelitian ini akan diungkapkan peran wisatawan. Sebagai penelitian awal, dilakukan kajian aktivitas wisatawan di daerah wisata pantai ini, persepsi wisatawan mengenai obyek yang disukai di daerah kunjungan, serta peran obyek tersebut bagi wisatawan. Keseluruhan kajian memiliki fokus perhatian pada kemungkinan penurunan 
populasi Gastropoda, sebab pemanenan siput laut yang berlebihan pada akhirnya akan menjadi kendala pengembangan wisata pantai.

\section{Metode Penelitian}

Wisatawan diwawancara secara langsung dengan panduan kuesioner yang telah dipersiapkan sebelumnya. Wisatawan diwawancara secara accidental sampling, yaitu wisatawan yang saat itu secara kebetulan berada di lokasi penelitian, Pantai Krakal. Jumlah sampel tidak ditentukan terlebih dahulu, apabila responden yang ada sudah mencukupi, yang ditandai dengan jawabanjawaban yang memiliki variasi yang kecil atau konstan, maka pengambilan sampel dihentikan (Nawawi, 1998). Analisa data hasil kuesioner menggunakan metode deskriptif kualitatif (Nazir, 1988).

\section{Hasil dan Pembahasan}

Distribusi karakteristik responden dapat dilihat pada Tabel 1. Nampaknya, lebih dari $85 \%$ wisatawan berumur 14-25 tahun, dengan pendidikan terbanyak SMU $(55,8 \%)$, dan pekerjaan: pelajar dan mahasiswa $(77,9 \%)$. Komposisi mayoritas kalangan terpelajar ini nampaknya memberi pengaruh pada jawaban responden pada pertanyaan-pertanyaan lain yang diajukan.

Tabel 1. Karakteristik responden wisatawan Pantai Krakal

\begin{tabular}{|c|c|c|c|c|c|}
\hline \multicolumn{2}{|c|}{ Karakteristik Responden } & \multicolumn{2}{|c|}{ Jumlah Responden } & \multicolumn{2}{|c|}{ Persentase } \\
\hline \multirow[t]{2}{*}{ Jenis Kelamin } & Perempuan & \multirow{2}{*}{\multicolumn{2}{|c|}{$\begin{array}{l}43 \\
43\end{array}$}} & \multirow{2}{*}{\multicolumn{2}{|c|}{$\begin{array}{l}50 \\
50\end{array}$}} \\
\hline & Laki-laki & & & & \\
\hline \multirow[t]{4}{*}{ Umur } & $14-19$ & 39 & 74 & 45,3 & 86 \\
\hline & $20-25$ & 35 & & 40,7 & \\
\hline & $26-31$ & 6 & 12 & 7 & 14 \\
\hline & 32 atau lebih & 6 & & 7 & \\
\hline \multirow[t]{4}{*}{ Pendidikan } & SMP & \multicolumn{2}{|c|}{3} & \multicolumn{2}{|c|}{3,5} \\
\hline & SMA & \multicolumn{2}{|c|}{48} & \multicolumn{2}{|c|}{55,8} \\
\hline & D3 & \multicolumn{2}{|c|}{10} & \multicolumn{2}{|c|}{11,6} \\
\hline & S1 & \multicolumn{2}{|c|}{25} & \multicolumn{2}{|c|}{29,1} \\
\hline \multirow[t]{3}{*}{ Pekerjaan } & Pelajar dan mahasiswa & \multicolumn{2}{|c|}{67} & \multicolumn{2}{|c|}{77,9} \\
\hline & Karyawan PNS dan Swasta & \multicolumn{2}{|c|}{17} & \multicolumn{2}{|c|}{19,8} \\
\hline & Pengangguran & \multicolumn{2}{|c|}{2} & \multicolumn{2}{|c|}{2,3} \\
\hline
\end{tabular}

Keterangan: $\mathrm{N}=86$, data diolah dari Andi (2003)

Tabel 2. Sebaran frekuensi kunjungan tahun 2002

\begin{tabular}{|c|c|c|c|c|}
\hline Frekuensi Kunjungan (tahun) & \multicolumn{2}{|c|}{ Jumlah } & \multicolumn{2}{|c|}{ Persentase } \\
\hline Satu kali & \multicolumn{2}{|c|}{40} & \multicolumn{2}{|c|}{46,5} \\
\hline Dua kali & 20 & 46 & 23,3 & 53,5 \\
\hline Tiga kali & 8 & & 9,3 & \\
\hline Lebih dari tiga kali & 18 & & 20,9 & \\
\hline
\end{tabular}

Keterangan: $\mathrm{N}=86$, data diolah dari Andi (2003)

Sebanyak 46,5\% wisatawan menyatakan berkunjung ke Pantai Krakal sekali dalam setahun, sementara 23,3\% menyatakan dua kali melakukan kunjungan, dan 20,9\% bahkan telah lebih dari tiga kali melakukan kunjungan tahun tersebut. Repetisi kunjungan menunjukkan bahwa daya tarik wisata daerah pantai memang cukup diminati. Jika kita menjumlah seluruh wisatawan yang melakukan repetisi kunjungan maka didapatkan 53,5\% (Tabel 2.). Artinya lebih dari separuh total wisatawan kembali lagi ke daerah tujuan wisata ini. Kecenderungan 
wisatawan untuk mendatangi daerah wisata alam dibandingkan kunjungan ke obyek wisata lain (bukan wisata alam) memang telah banyak dilaporkan. Hal ini terjadi karena nampaknya obyek alamiah lebih memberikan daya tarik untuk escape from routine. Alasan lainnya adalah obyek wisata alam mampu memberikan pengalaman menyenangkan dengan biaya murah. Bagi kalangan muda, berjalan dan bermain air laut memberikan tantangan ringan yang menyenangkan (lihat juga Tabel 5.).

Tabel 3. Obyek wisata yang menarik perhatian

\begin{tabular}{lcccc}
\hline \multicolumn{1}{c}{ Benda } & \multicolumn{2}{c}{ Jumlah } & \multicolumn{2}{c}{ Persentase } \\
\hline \hline Suvenir dari siput/kerang & 34 & 68 & 39,5 & 79 \\
Cangkang & 34 & & 39,5 & \\
Karang Hidup & \multicolumn{2}{c}{12} & & 14 \\
Ikan dan atau Tumbuhan Laut & \multicolumn{2}{c}{6} & & 7 \\
\hline \hline
\end{tabular}

Keterangan: $\mathrm{N}=86$, data diolah dari Andi (2003)

Sebanyak 39,5\% menyatakan obyek yang menarik perhatian saat ke pantai adalah suvenir (barang kerajinan) dari siput dan kerang, sedang 39,5\% menyatakan yang menarik adalah cangkang (siput dan kerang yang tidak dalam bentuk barang kerajinan), artinya $79 \%$ menyatakan siput dan keranglah yang menarik perhatian mereka ketika berkunjung ke daerah wisata pantai ini (baik dalam bentuk suvenir maupun tidak). Sementara karang terumbu dan ikan serta tumbuhan laut menduduki peringkat yang lebih rendah (Tabel 3.). Dari jawaban pengunjung, nampaknya ada konsistensi bahwa kesukaan akan siput dan kerang serta kegiatan bermain airlah yang membuat mereka kembali lagi berkunjung ke pantai (lihat juga Tabel 5.).

Tabel 4. Frekuensi perjumpaan dengan siput/kerang

\begin{tabular}{lccc}
\hline \hline & Perjumpaan & Jumlah & Persentase \\
\hline \hline Jumpa & 61 & 70,9 \\
Tidak & 25 & 29,1 \\
\hline \hline
\end{tabular}

Keterangan: $\mathrm{N}=86$, Andi (2003)

Frekuensi perjumpaan dengan siput dan atau kerang menunjukkan mudah tidaknya akses pemanenan siput maupun kerang oleh wisatawan. Dari data ini (Tabel 4.) diharapkan juga diketahui gambaran populasi siput secara tidak langsung. Sebanyak 70,9 \% menyatakan selalu berjumpa siput dan atau kerang sedangkan sisanya $29,1 \%$ menyatakan tidak berjumpa siput ataupun kerang. Jadi nampaknya meskipun siput ini rata-rata berukuran kecil, namun ketertarikan terhadap obyek ini menjadikannya terlihat. Bisa jadi karena mereka begitu mudah diakses untuk dipanen maka obyek ini dimungkinkan diambil untuk kenang-kenangan pribadi perjalanan mereka.

Tabel 5. Aktivitas yang dilakukan wisatawan

\begin{tabular}{lcc}
\hline \multicolumn{1}{c}{ Aktivitas } & Jumlah & Persentase \\
\hline \hline Bermain air laut/duduk/jalan-jalan & 68 & 79 \\
Mencari siput/kerang & 9 & 10,5 \\
Mencari ikan hias & 6 & 7 \\
Mengumpulkan potongan karang terumbu & 3 & 3,5 \\
\hline \hline
\end{tabular}

Keterangan: $\mathrm{N}=86$, data diolah dari Andi (2003) 
Dari aktivitas yang dilakukan wisatawan, sebagian dari mereka $79 \%$ hanya bermain-main air saja, duduk atau berjalan-jalan, sehingga sebagian besar tidak beraktivitas yang merusak alam beserta biota yang hidup didalamnya. Sebagian lain hanya mengumpulkan potongan karang yang halus (terbawa ombak ke tepi). Data Tabel 5. menunjukkan bahwa yang mengambil siput dan kerang hanya sebesar $10,5 \%$ dari 86 wisatawan yang disurvai. Jadi jawaban ini menunjukkan bahwa meskipun akses untuk mengambil siput besar karena mudah terlihat dan mudah diambil (gerakannya lambat), namun mereka tidak menggunakan kesempatan tersebut untuk memanen siput untuk kenang-kenangan. Apakah perilaku ini dikarenakan kesadaran mereka akan upaya pelestarian, atau karena kebutuhan untuk escape from routine lebih menonjol? Nampaknya kegiatan bermain air laut, duduk dan jalan-jalan lebih menarik. Sebagai tambahan, yang mungkin harus diwaspadai adalah aktivitas mencari ikan di pantai ini, yang amat berpotensi merusak alam. Di Pantai Kukup kegiatan ini difasilitasi dengan dijualnya jaring bertangkai, yang mudah digunakan wisatawan dan sengaja dijual penduduk untuk digunakan beraktivitas yang mengancam sumber daya alam. Namun sekali lagi nampaknya upaya wisatawan dibanding upaya penduduk setempat yang memanen ikan belum dapat diperbandingkan.

Tabel 6. Pendapat mengenai peran Gastropoda

\begin{tabular}{lcc}
\hline \hline \multicolumn{1}{c}{ Pernyataan } & Jumlah & Persentase \\
\hline \hline Biota laut yang indah dan unik & 65 & 75,6 \\
Biota laut yang tidak boleh diganggu & 12 & 14,0 \\
Bahan cinderamata & 5 & 5,8 \\
Bahan makanan alternatif & 4 & 4,7 \\
\hline \hline
\end{tabular}

Keterangan: $\mathrm{N}=86$, Andi (2003)

Tabel 7. Pendapat mengenai keindahan Gastropoda

\begin{tabular}{lcc}
\hline \hline \multicolumn{1}{c}{ Pernyataan } & Jumlah & Persentase \\
\hline \hline Bentuk unik dan variatif & 61 & 70,9 \\
Warna cemerlang & 21 & 24,4 \\
Saat berenang atau mengapung & 2 & 2,3 \\
Saat berjalan/bergerak & 2 & 2,3 \\
\hline \hline
\end{tabular}

Keterangan: $\mathrm{N}=86$. data diolah dari Andi (2003)

Nampaknya wisatawan sadar bahwa siput laut adalah biota yang indah dan unik $(75,6 \%)$ sayang yang menyatakan tidak boleh diganggu hanya 14\% (Tabel 6.). Sementara 5,8 $\%$ hanya menganggap sebagai bahan cindera mata saja, dan yang lain $4,7 \%$ menganggap sebagai bahan makanan alternatif. Lebih lanjut, wisatawan merinci bahwa keindahan
Gastropoda adalah pada bentuknya yang unik dan bervariasi (70,9\%, Tabel 7.). Sebanyak $24,4 \%$ wisatawan menganggap warnanya lebih menarik dibanding kriteria yang lain. Pertanyaan ini diarahkan untuk melihat kemungkinan motivasi wisatawan yang menggerakkannya untuk melakukan pengambilan.

Tabel 8. Tindakan yang dilakukan wisatawan saat menjumpai Gastropoda hidup

\begin{tabular}{llccc}
\hline \hline \multicolumn{1}{c}{ Tindakan } & Jumlah & \multicolumn{2}{c}{ Persentase } \\
\hline \hline Diambil untuk dilihat & 34 & 57 & 39,5 & 66,2 \\
Dibiarkan saja & 23 & & 26,7 & \\
Diambil untuk dikoleksi & 18 & 29 & 20,9 & 33,8 \\
Diambil untuk dipelihara & 11 & & 12,8 & \\
\hline \hline
\end{tabular}

Keterangan $\mathrm{N}=86$, data diolah dari Andi (2003) 
Tabel 8. lebih langsung mengarahkan wisatawan pada tindakan yang akan mereka ambil saat menjumpai Gastropoda di sekitar mereka. Dua pilihan pertama merupakan pilihan yang tidak memberi akibat pada populasi di alam, sementara dua pilihan kedua akan mengurangi populasi di alam. Wisatawan yang memilih alternatif dua pilihan pertama sebanyak $66,2 \%$, sementara yang memilih dua pilihan kedua sebanyak 33,8\%. Tentu jawaban ini cukup melegakan karena persentase wisatawan yang berpotensi merusak populasi Gastropoda di alam relatif kecil. Hanya saja bila kita analisa lebih lanjut, tentu akan lebih baik jika dapat diketahui, jumlah yang diambil wisatawan dibandingkan jumlah yang diambil pemanen rutin yaitu penduduk lokal (Zahida et.al., 2005). Meskipun secara kasar dapat diketahui bahwa jumlah yang diambil wisatawan jauh lebih kecil dibandingkan yang dipanen penduduk, namun perbandingan angka yang pasti belum bisa didapatkan dari penelitian yang telah dilakukan. Bagaimanapun bagi wisatawan, kegiatan mereka lebih sebagai kegiatan untuk kesenangan sesaat saja dan dilakukan sambil lalu, artinya tidak ada intensi untuk memanen.

Tabel 9. Pendapat wisatawan mengenai kegunaan Gastropoda

\begin{tabular}{lcccc}
\hline \multicolumn{1}{c}{ Pernyataan } & \multicolumn{2}{c}{ Setuju } & \multicolumn{2}{c}{ Tidak Setuju } \\
\cline { 2 - 5 } & Jumlah & Persentase & Jumlah & Persentase \\
\hline \hline Gastropoda sebagai koleksi wisatawan & 42 & 48,8 & 44 & 51,2 \\
$\begin{array}{l}\text { Gastropoda sebagai Suvenir, menunjang } \\
\text { ekonomi masyarakat }\end{array}$ & 58 & 67,4 & 28 & 32,6 \\
\hline \hline
\end{tabular}

Keterangan N = 86, Andi (2003)

Respons wisatawan mengenai kegunaan Gastropoda menarik untuk disimak, karena nampaknya ada ketidak sesuaian antara pilihan jawaban satu terhadap yang lainnya (Tabel 9). Ada dua pilihan disini, yaitu apakah wisatawan setuju jika Gastropoda dikoleksi wisatawan $(48,8 \%)$ atau difungsikan sebagai penunjang ekonomi masyarakat. Wisatawan tidak setuju Gastropoda dikoleksi wisatawan (51,2\%), namun setuju dibuat sebagai suvenir sehingga diharapkan menunjang ekonomi masyarakat $(67,4 \%)$. Wisatawan terlihat punya pendapat yang tidak konsisten. Bagaimana mungkin wisatawan setuju Gastropoda untuk menunjang ekonomi masyarakat tanpa dikoleksi wisatawan? Dalam masyarakat modern hal itu dimungkinkan hanya jika, wisatawan dengan membayar biaya masuk kawasan wisata, melihat Gastropoda di alam telah merasa cukup, tanpa perlu membawa suvenir berupa cindera mata ataupun cangkang siput. Masalahnya apakah retribusi yang masuk ke pemda dapat sampai ke masyarakat secara langsung. Jika belum bisa maka pendapat wisatawan tersebut agak kurang rasional. Sebagai catatan responden yang tidak setuju maupun yang setuju untuk pernyataan Gastropoda sebagai koleksi wisatawan memiliki proporsi hampir sama, sehingga kurang signifikan perbedaannya (Tabel 9).

Tabel 10. Pendapat wisatawan mengenai pengertian pantai

\begin{tabular}{llllc}
\hline \multicolumn{1}{c}{ Pernyataan } & Jumlah & \multicolumn{2}{c}{ Persentase } \\
\hline \hline Tempat kehidupan biota laut & 28 & 49 & 32,6 & 57 \\
Tempat wisata alam & 21 & & 24,4 & 43 \\
\hline Kekayaan alam yang tidak pernah habis & 19 & 37 & 22,1 & 20,9 \\
Potensi alam yang memberikan & 18 & & & \\
keuntungan & & & & \\
\hline \hline
\end{tabular}

Keterangan $\mathrm{N}=86$, data diolah dari Andi (2003) 
Pendapat wisatawan mengenai beberapa pengertian pantai dapat dikelompokkan dalam dua pernyataan yang berkonotasi environment friendly (57\%) dan economic friendly (43\%, Tabel 10.). Wisatawan yang lebih memperhatikan kepentingan lingkungan, 32,6 persen memandang pantai sebagai kehidupan biota dan 24,4 persen sebagai tempat wisata alam. Wisatawan yang lebih menekankan faktor ekonomis, 22,1 persen menyatakan pantai memiliki kekayaan alam yang tidak pernah habis, dan 20,9 persen menyatakan pantai sebagai potensi alam yang memberi keuntungan bagi manusia. Pernyataan bahwa kekayaan alam tak pernah habis, merupakan paradigma lama yang harus diubah, mengingat kecepatan kemajuan teknologi telah membuat kekayaan alam yang tak pernah habis menjadi mendekati habis, terutama untuk produk sumber daya hayati yang bisa diperbaharui. Fakta telah menunjukkan bahwa populasi berbagai produk perikanan mulai kolaps, dan banyak produk yang semula bukan menjadi komoditi utama telah mengeser produk utama yang telah habis.

\section{Kesimpulan}

Studi ini mendapatkan bahwa mayoritas pengunjung adalah usia sekolah $86 \%$. Usia ini memiliki ciri kesukaan akan wisata yang memiliki atraksi yang menantang. Pantai yang berombak, berpasir putih, cocok sekali untuk bermain air dan berjalan-jalan (79\%), sehingga memberikan kepuasan bagi usia ini. Hal ini tampak dari frekuensi kunjungan wisatawan lebih dari sekali 53,5\%. Obyek yang menarik wisatawan untuk berkunjung adalah siput dan kerang, baik berupa barang kerajinan maupun bukan $79 \%$. Sebanyak 70,9\% wisatawan selalu menjumpai siput dan kerang di pantai, mereka menganggapnya sebagai biota yang indah dan unik $(75,6 \%)$ sayang yang menyatakan tidak boleh diganggu hanya $14 \%$, wisatawan merinci bahwa keindahan Gastropoda adalah pada bentuknya yang unik dan bervariasi 70,9\%, namun ketertarikan mereka tidak menggerakkan mereka untuk mengkoleksi, cukup bagi mereka untuk melihat dan membiarkan saja 66,2\%. Wisatawan tidak setuju Gastropoda dikoleksi pengunjung $(51,2 \%)$, namun setuju dibuat sebagai suvenir sehingga diharapkan menunjang ekonomi masyarakat $(67,4 \%)$. Wisatawan cukup sadar bahwa mereka harus melindungi daerah kunjungan wisata alam ini dan ini terlihat dari kecenderungan untuk environment friendly (57\%) dibanding economic friendly (43\%).

\section{Saran}

Penelitian ini belum dapat menunjukkan hubungan sebab akibat dari satu pernyataan ke pernyataan yang lain, sehingga perlu dipastikan suatu perilaku (tercermin dalam jawaban) dilakukan atas dasar alasan tertentu yang jelas. Satu hal yang perlu diperjelas adalah dapatkah diperbandingkan jumlah pengambilan oleh pengunjung dan oleh penduduk pemanen, meskipun keduanya memiliki motivasi yang jelas berbeda.

\section{Daftar Pustaka}

Andi, S.A., 2003. Studi Keanekaragaman Gastropoda dan Profil Wisatawan di Pantai Krakal, Yogyakarta. Skripsi. Fakultas Biologi, Universitas Atma Jaya Yogyakarta.

Cahyaningrum, S.Y. 2005. Menjelajahi Pantai Sepanjang 72 Km Gunung Kidul. Harian Kompas, 4 Maret 2005

Nawawi, H. 1998. Metode Penelitian Sosial. Universitas Gadjah Mada Press. Cetakan 8. Yogyakarta.

Nazir, 1988. Metode Penelitian. PT Ghalia Indonesia. Jakarta.

Zahida, F., Sinulingga, M.B. dan Jati, W.N. 2005. Kajian Awal Pemanenan Siput Laut (Gastropoda) Di Pantai Krakal, Yogyakarta: II. Aktivitas Pemanen. Biota. X (1): 24-30 